\title{
CONF-9508218--2
}

\section{The Economics of Biomass Production in the United States}

\author{
Robin L. Graham \\ Environmental Sciences Division \\ Oak Ridge National Laboratory ${ }^{1}$ \\ Oak Ridge, TN \\ Erik Lichtenberg \\ University of Maryland \\ College Park, MD \\ Vernon O. Roningen \\ ERS-USDA \\ Washington, DC \\ Houssein Shapouri \\ OENU-ERS-USDA \\ Washington, DC \\ Marie E. Walsh \\ Energy Division \\ Oak Ridge National Laboratory ${ }^{1}$ \\ Oak Ridge, TN
}

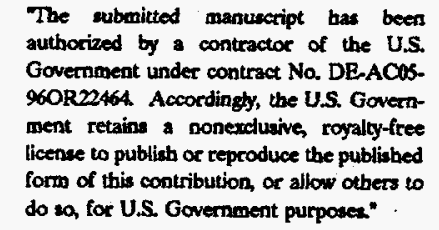

1 Oak Ridge National Laboratory, managed by Lockheed Martin Energy Research Corporation for the U.S. Department of Energy under contract number DE-AC05-960R22464 


\section{DISCLAIMER}

This report was prepared as an account of work sponsored by an agency of the United States Government. Neither the United States Government nor any agency thereof, nor any of their employees, makes any warranty, express or implied, or assumes any legal liability or responsibility for the accuracy, completeness, or usefulness of any information, apparatus, product, or process disclosed, or represents that its use would not infringe privately owned rights. Reference herein to any specific commercial product, process, or service by trade name, trademark, manufacturer, or otherwise does not necessarily constitute or imply its endorsement, recommendation, or favoring by the United States Government or any agency thereof. The views and opinions of authors expressed herein do not necessarily state or reflect those of the United States Government or any agency thereof. 


\title{
The Economics of Biomass Production in the United States
}

Robin L. Graham, Ph.D., Economist, ORNL, Oak Ridge, TN, USA

Erik Lichtenberg, Ph.D., University of Maryland, College Park, MD, USA Vernon O. Roningen, Ph.D., Economist, ERS-USDA, Washington, DC, USA Hossein Shapouri, Ph.D., Economist, OENU-ERS-USDA, Washington, DC, USA Marie E. Walsh, Ph.D., Economist, ORNL, Oak Ridge, TN, USA

\begin{abstract}
Biomass crops (e.g. poplar, willow, switchgrass) could become important feedstocks for power, liquid fuel, and chemical production. With successful research programs that boost crop yields and develop appropriate power and chemical conversion technologies, biomass might compete with fossil fuels for a broad range of uses. Compared to fossil fuels, biomass feedstocks can offer significant environmental benefits. For example, biomass crops do not add greenhouse gases to the atmosphere during their life cycle.
\end{abstract}

This paper presents estimates of the potential production of biomass in the United States under a range of assumptions. Estimates of potential biomass crop yields and production costs from the Department of Energy's (DOE) Oak Ridge National Laboratories (ORNL) are combined with measures of land rents from USDA's Conservation Reserve Program (CRP), to estimate a competitive supply of biomass wood and grass crops. Estimates are made for one potential biomass use--electric power production--where future costs of electricity production from competing fossil fuels set the demand price. The paper outlines the methodology used and limitations of the analysis.

Currently, biomass-based electricity generation is a niche market where electricity is expensive and fuel is cheap or incurs a disposal cost, e.g. waste wood, sawdust, etc. However, if biomass production and usage systems demonstrate themselves to be workable at DOE's projected costs, biomass crops might become competitive for electricity production and other uses. Increases in fossil fuel prices, more rapid advances in gassification-gas turbine power generation technology, or rapid market development for biomass-based co-products such as pulp wood or chemicals could accelerate the production of biomass for electricity generation. Policies that discourage greenhouse gas emissions or encourage biofntss production on idle land could also make biomass feedstocks more calpetitive with fossil fuels for a range of uses.

Biomass crops could be produced on some of the land idled by farm programs in recent years. However, if biomass crop production should expand beyond 30 million acres, then the interaction of biomass with traditional agricultural crops, markets, and programs becomes important. While the outlook for biomass feedstocks for energy and other uses offers promise, the practical viability of biomass production and usage systems needs to be demonstrated. Given the uncertainty about the competitiveness of the biomass industry, projects that successfully demonstrate biomass production and utilization systems hold the key to the future of biomass production in the United States 


\section{Background}

This paper discusses the economic potential of biomass production and utilization. Biomass crops are being promoted as feedstocks for the production of electric power, liquid fuels, and chemicals. Biomass feedstocks have environmental advantages compared to fossil fuels. For example, they would not add greenhouse gasses to the atmosphere during their life cycle. These crops might be grown on fragile lands and could perform other environmental tasks such as the filtration of fertilizer and pesticide runoff. DOE research suggests that yields of biomass crops such as poplar, willow, and switchgrass could be increased significantly. If new generation efficient gassification systems and turbines were developed for power production, biomass might become competitive with fossil fuels as an energy source. Such a development would benefit farmers by adding energy crops to traditional food and fiber production. Rural communities would benefit from jobs created by biomass production and utilization.

\section{Methodology}

The supply of a product is the quantity that will be produced with a unit of resources at a price that is competitive with other uses for the same resources. Given a fixed amount of biomass production, the competitive price is set by the last unit of resources coming into production which just meets production expenses. The potential supply of biomass can be estimated given data on land productivity, biomass production costs, and the cost of land for alternative uses. Since biomass crops have a life cycle of several years, the stream of biomass revenues and costs has to be discounted in order to compare returns from biomass production with alternative investments (Strauss and Wright).

The supply price estimates for biomass on an acre of land can be done by calculating the present value of estimated revenue and costs over a production cycle ( $\mathrm{n}$ years). Let $\mathrm{p} \equiv$ average annual biomass crop price per ton harvested, $y_{t} \equiv$ biomass yield per acre (in period $t$ ), $a_{\equiv} \equiv$ total production cost per acre (including a competitive return to the land), and $r \equiv$ the discount rate over the crop cycle period. For each acre of biomass, the discounted

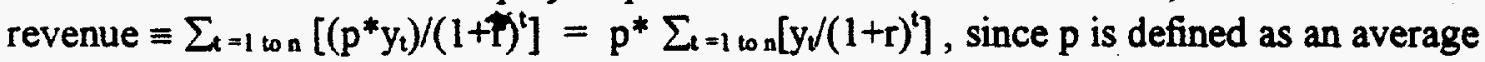
price over the crop cycle. This discounted revenue from biomass production must equal

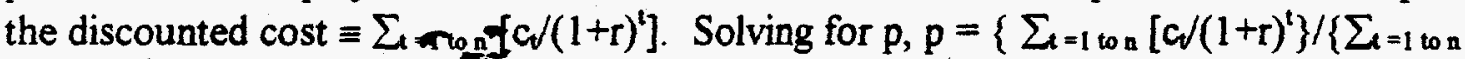
$\left.\left[y_{t} /(1+r)^{t}\right]\right\}$. The average biomass supply price depends on the ratio of discounted production cests to iscoented yields (resource productivity). This calculation was repeated for land units with differing productivity (yields) and value (rental rates).

The quantity of biomass produced on a unit of land is simply the area times the average annual yield. The total quantity $q$ supplied to the market at a price $p$ is the sum of production on all land where the equivalent discounted price $<=p$ ( $p$ is the marginal price for the last unit of land to go into production at that price). Land units were ranked by their estimated "break even" price $p$, and production was summed over all units of land with an equal or lower price. This calculation gives the total quantity of biomass produced at each price level (current prices), i.e. the potential biomass supply. 
A data set for four potential biomass production regions in the United States was created. Acreage was broken down into land units by land capability class (Walsh and Graham, 1995) and average land rental values from the 12th sign-up of USDA's Conservation Reserve Program (Osborn, Liacuna, and Linsenbigler, 1992). Data on potential biomass yields and production costs by land class was assembled by ORNL for land suitable for biomass (crop, CRP, and pasture land with medium to high conversion potential) in the four regions shown in Figure 1. Calculations assume that biomass yields, production budgets, and CRP land rents applied to all land in a unit. Switchgrass was the representative grass crop while poplar was the wood crop for all regions except for willows in the North East. The yield scenarios (labeled by year) represented judgments about the potential success of biomass research programs: 2000 - yields attainable with current technology, 2005 - yields with improved management and clonal and varietal selection, and 2020 - yields that could be achieved with a sustained multi-regional genetic improvement program. Table 1 summarizes the data set used for estimation of the potential biomass supply in the U.S.

Table 1: Potential Biomass Crops, Suitable Acreages, and Average Yields 1/

\begin{tabular}{|c|c|c|c|c|c|c|c|c|c|c|}
\hline \multirow{3}{*}{ Region } & \multicolumn{5}{|c|}{ 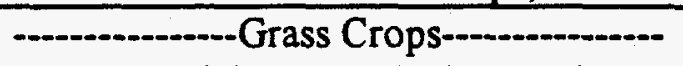 } & \multicolumn{5}{|c|}{ Wood Crops- } \\
\hline & \multirow[t]{2}{*}{ Crop } & \multirow[t]{2}{*}{$\begin{array}{l}\text { Million } \\
\text { Acres }\end{array}$} & \multicolumn{3}{|c|}{$\begin{array}{l}\text { Yield Scenarios } \\
\text { (Dry Tons/Acre) }\end{array}$} & \multirow[t]{2}{*}{ Crop } & \multirow[t]{2}{*}{$\begin{array}{l}\text { Million } \\
\text { Acres }\end{array}$} & \multicolumn{3}{|c|}{$\begin{array}{l}\text { Yield Scenarios } \\
\text { (Dry Tons/Acre) }\end{array}$} \\
\hline & & & 2000 & 2005 & 2020 & & & 2000 & 2005 & 2020 \\
\hline North & Switch & & & & & & & & & \\
\hline Central & grass & 200 & 4.2 & 4.8 & 6.0 & Poplar & 177 & 3.1 & 5.1 & 7.1 \\
\hline North & Switch & & & & & & & & & \\
\hline East & grass & 36 & 3.7 & 4.3 & 5.3 & Willow & 36 & 4.2 & 6.4 & 8.1 \\
\hline South & Switch & & & & & & & & & \\
\hline Central & grass & 64 & 5.1 & 5.9 & 7.4 & Poplar & 41 & 2.6 & 4.6 & 6.8 \\
\hline $\begin{array}{l}\text { South } \\
\text { East }\end{array}$ & $\begin{array}{l}\text { Switch } \\
\text { grass }\end{array}$ & 22 & 6.0 & 6.9 & 8.6 & Poplar & 22 & 3.0 & 5.0 & 7.3 \\
\hline $\begin{array}{l}1 / \text { Prod } \\
\text { poplar - } \\
\text { rainfall. } \\
\text { observat } \\
\text { East - 60 } \\
\text { yields as } \\
\text { switchgr } \\
\text { rents (an } \\
\text { North E }\end{array}$ & $\begin{array}{l}\text { Acreage } \\
\text { lons wer } \\
\text { signed to } \\
\text { ass budg } \\
\text { d standa }\end{array}$ & $\begin{array}{l}\text { North } \\
\text { ata incluc } \\
\text { each. Cr } \\
\text { ts, } 3 \text { pop } \\
\text { d deviati }\end{array}$ & od 12 & $\begin{array}{l}182, \mathrm{~N} \\
\text { nd capa } \\
\text { ets wer } \\
\text { ets, and }\end{array}$ & $\begin{array}{l}\text { orth } \mathrm{Ea} \\
\text { bility cl } \\
\text { assign }\end{array}$ & $\begin{array}{l}t-91, S \\
\text { isses/sub } \\
d \text { to lanc }\end{array}$ & asses wi & $\begin{array}{l}1-61, \\
\text { differe } \\
\text { ORNL }\end{array}$ & it pot & $\begin{array}{l}\text { years, } \\
\text { te } \\
\text { rental } \\
\text { h } \\
\text { tial } \\
\text { up } \\
\text { 1), }\end{array}$ \\
\hline
\end{tabular}


Figure 2 shows a sample ORNL switchgrass crop budget and associated average yield scenarios for 2000, 2005, and 2020 for the North Central region. Budgets included variable cash, labor, and operating capital costs of production. This data was combined with a 6.5 percent discount rate and a CRP rental rate for the land unit (representing the required return from the land to cover ownership costs, profits, and taxes) to calculate an annualized farmgate price (cost) per ton that would allow normal returns for the land owner, given estimated revenues and costs. Budgets did include some variation in production costs associated with different yields (e.g. harvesting, transportation).

Figure 2: Switchgrass Production Budget Spreadsheet For a North Central Region Unit of Land With ORNL Yields and CRP Land Rent

\begin{tabular}{|c|c|c|c|c|c|c|c|}
\hline & A & $\mathbf{B}$ & C & D & $E$ & $\boldsymbol{F}$ & $\mathbf{G}$ \\
\hline 2 & Switchorass Budget & $\begin{array}{r}\text { 2000-YR. } 1 \\
\text { ESTAB. } \\
\text { COST }\end{array}$ & $\begin{array}{r}2000 \text {-YRS. } 2 \\
10 \text { ANNUAL } \\
\text { MANT. } 8 \\
\text { HARV. COST }\end{array}$ & $\begin{array}{r}2008-Y R, 1 \\
\text { ESTAB, COST }\end{array}$ & $\begin{array}{r}\text { 2005.YRS. } 2 \\
10 \text { ANNUAL } \\
\text { MANT. } 8 \\
\text { HARV. COST }\end{array}$ & $\begin{array}{r}\text { 2020-YR. } 1 \\
\text { ESTAB. } \\
\text { COST }\end{array}$ & $\begin{array}{r}2020 \text {-YRS. } 2 \\
10 \text { ANNUAL } \\
\text { MANT. } \\
\text { HARY. COST }\end{array}$ \\
\hline 3 & VARIABLE CASH COS & STS & & & & & \\
\hline 4 & 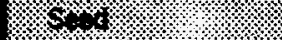 & 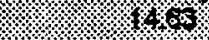 & & $3 \%$ & & 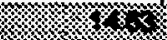 & \\
\hline 5 & $8+40$ & 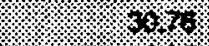 & 698 & $x=0$ & $8 \times$ & 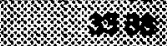 & $3<$ \\
\hline 6 & $01,4,-4$ & $18 \%$ & & $8<8$ & & $8 x^{2}, 1$ & \\
\hline 7 & $f(x+4)=$ & 44 & $0 \%$ & \% & 34 & 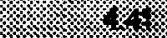 & 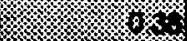 \\
\hline 8 & $60,0,1,1$ & $80 \%$ & $8 \%$ & $6 x$ & 30 & 8 & 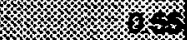 \\
\hline 9 & man & & 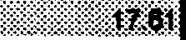 & & sos & & 6 \\
\hline 17 & $\begin{array}{l}\text { COSTS OF OWNED } \\
\text { RESOURCES }\end{array}$ & & & & & & \\
\hline 18 & 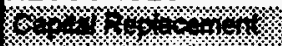 & wo & ox & $x<$ & $3 \%$ & 3 & 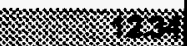 \\
\hline 19 & 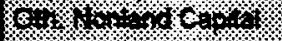 & 6 & $\%$ & $\%$ & $x=3$ & $x$ & 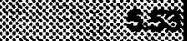 \\
\hline 21 & 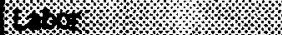 & 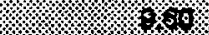 & so & 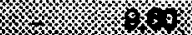 & K & 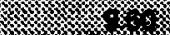 & 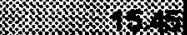 \\
\hline 24 & Present Value (PV) Cc & ost Calc. (1993 & (iAcre) & & & & \\
\hline 26 & Discount rate $(\%)$ & $3 / 2, y \%$ & Assumed Tra & isport Cost (3/) & & & \\
\hline 28 & $\begin{array}{l}\text { Annual land rental } \\
\text { rate-CRP data: }\end{array}$ & $\% 3$ & 3.00 & PV-2000 & PV-2008 & PV-2020 & \\
\hline 27 & $A=R .4-8, C . B, D, F$ & Estab. cost-yr. 1 & & 71.15 & 72.19 & 74.27 & \\
\hline 28 & $B=R, 4-8, C, C, E, G$ & Maint. harv. cost- & $-2-10$ & 269.24 & 277.36 & 311.91 & \\
\hline 29 & $C=R .18-19.21: \mathrm{All}$ & Cap. lab. depr. -1 & & 207.75 & 221.60 & 242.63 & \\
\hline 30 & $D=R .26, C . B .0 . F$ & Land rental cost- & -1.10 & 566.55 & 566.55 & 566.55 & \\
\hline 31 & $=A+B+C+D$ & 10 Y. Farm C. 193 & 3 S/A) & 1114.69 & 1137.70 & 1195.36 & \\
\hline 32 & Yield Assum-ORNL: & Average (dry & onsiadicheport & jsts-yrs. 2-10 & \multirow{5}{*}{\multicolumn{3}{|c|}{$\begin{array}{l}\text { Calculations of annualized cost of } \\
\text { switchgrass production, given ORNL } \\
\text { budgets, yields, and land rental costs } \\
\text { from CRP data sources. }\end{array}$}} \\
\hline 33 & 2000 & mom & 70.25 & & & & \\
\hline 34 & 2005 & $\$ 2$ & 80.34 & & & & \\
\hline 36 & 2020 & 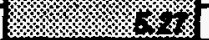 & 100.33 & & & & \\
\hline 36 & & & & & & & \\
\hline 37 & \multicolumn{2}{|c|}{ Annualiz. Farm C.JTon (93 S/Ton) } & Annualized Deli & ered Cost $(93, \pi)$ & \multirow{4}{*}{\multicolumn{3}{|c|}{$\begin{array}{l}\text { Shaded areas show budget data used. } \\
\text { Underlined numbers are resulting } \\
\text { annualized farm costs. }\end{array}$}} \\
\hline 38 & 2000 & 4760 & 50.60 & & & & \\
\hline 39 & 2005 & 42.48 & 46.48 & & & & \\
\hline 40 & 2020 & 36.74 & 38.74 & & & & \\
\hline
\end{tabular}

Figure 2 shows the calculations for an observation with a CRP rent of 74 dollars per acre that is expected to 3 eld 3 tons per acre of switchgrass in 2000, 4.2 tons in 2005, and 5.3 tons in 2020 . When similar spreadsheet calculations were performed for all rental observations in the North Central region, they were sorted by price (annualized farmgate cost). Then total acreage and production was cumulated for all land units with equal or lower prices. This process yielded a supply estimate with the lowest "break even" farmgate price per ton (left axis) verses the total acreage of land used (bottom axis) shown in Figure 3. The left part of the supply response scenario estimates shows the minimum price needed to bring switchgrass into production in competition with existing land use while the right part of the figure indicates the price that would be needed to bring all of the 
land in the North Central region into switchgrass production. The point representing the results of the spreadsheet calculation shown in Figure 2 is marked with a vertical line.

Figure 3: Potential Switchgrass Supply for the North Central Region

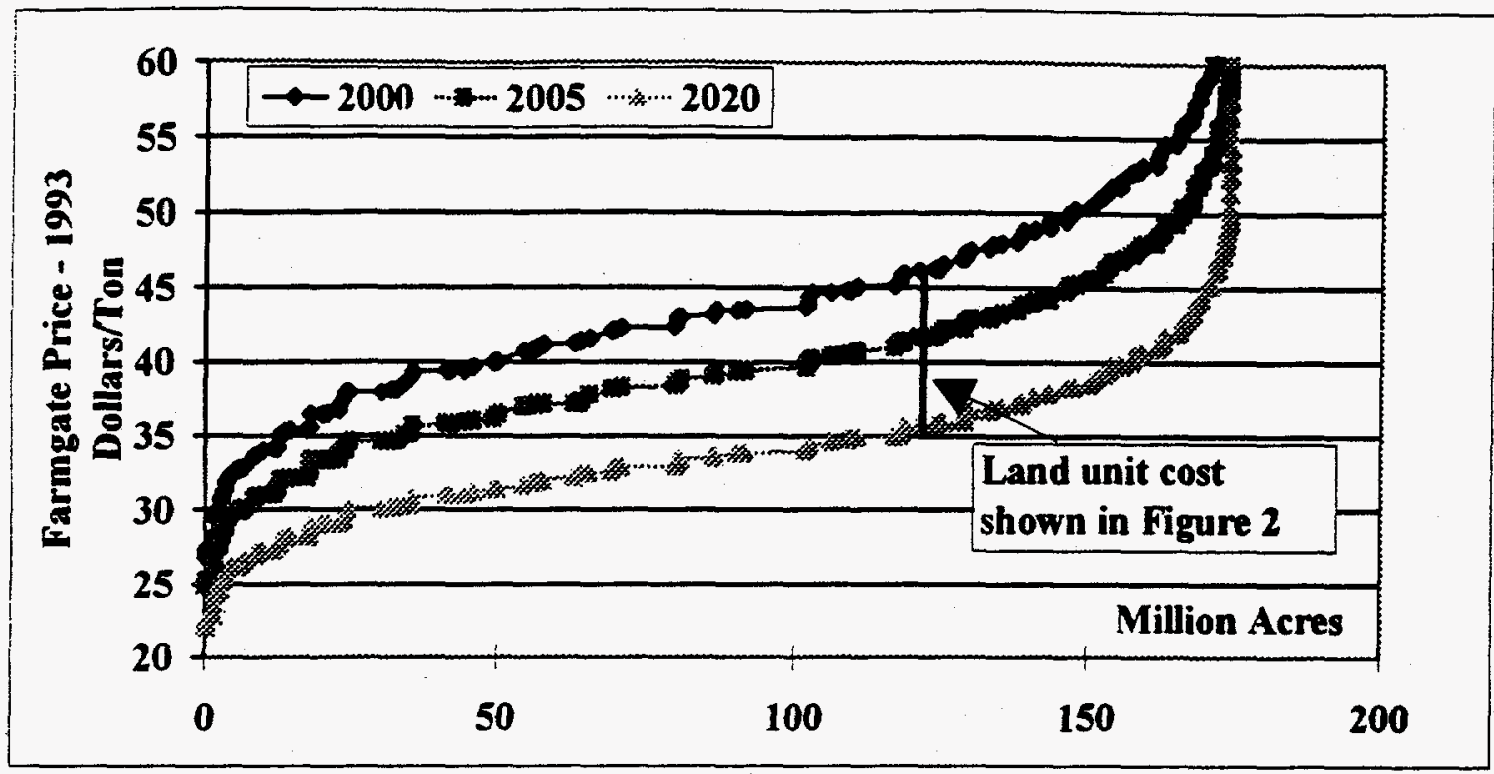

When the supply estimate is presented in terms of total acreage in a region, the scenarios with increased yields move the supply prices downward, i.e. they lower supply costs. Improved yields in 2005 with a modest research program lower costs at the line shown in Figure 3 from $\$ 47.60$ per ton to $\$ 42.48$, a reduction of $\$ 5.12$ per dry ton or 11 percent. By 2020 with a long term research program, the costs are lowered to $\$ 35.74$ per ton, down $\$ 11.86$ or 25 percent from the costs projected in 2000 . This calculation shows that given production costs and a variety of land prices and productivity; a) there is some land available that could produce switchgrass at a low price, e.g. $\$ 30$ or less per ton, b) if research programs could successfully increase yields, switchgrass at $\$ 30$ per ton would be competitive on more acreage (or at any of the acreages shown in Figure 3, the competitive price would be reduced). The calculation of a national biomass supply estimate follows the same methodology, combining land data from the four regions shown in Figure 1.

There is an important caveat about this type of analysis. The land rent distribution comes from a survey with existing crop production patterns in place. For example, the North Central region shown in Figme 1 has over 60 million acres in corn production, accounting for almost 80 percent of corn production land in the U.S. While Figure 3 suggests that all of this land could be converted to switchgrass production if prices approached $\$ 60$ per ton, the resulting removal of 80 percent of U.S. corn production would raise feed grain, livestock, and food prices dramatically. In turn this would raise the prices required to maintain all of this land in switchgrass production. Therefore the supply estimates using this methodology are appropriate for smaller acreages or biomass on idle land that is not competing with mainstream crops (e.g. the 50 million acres in conservation and crop setaside programs in recent years). If biomass crops were to seriously compete with traditional food and fiber crops, a full multi-commodity global market analysis would be needed to analyze the interaction of biomass crops with the existing farm economy. 


\section{Biomass Supply Estimates for the United States}

Figure 4 shows supply estimates for switchgrass on the lowest cost 50 million acres. The downward shift of supply prices in each scenario results from the yield increases assumed to follow from stepped-up research programs. The numbers in the table below the acreage show the total switchgrass production expected with each scenario. For example, a price of 28 dollars per dry ton would encourage production of 128 million tons on 20 million acres in the scenario for 2000. For 2005, 20 million acres could produce 146 million tons at a price of 26 dollars per ton. The 2020 scenario suggests the same 20 million acres could produce 159 million tons for less than 24 dollars per dry ton. The small amounts that could be produced under 25 dollars per ton with research progress, constitute a niche market that might develop.

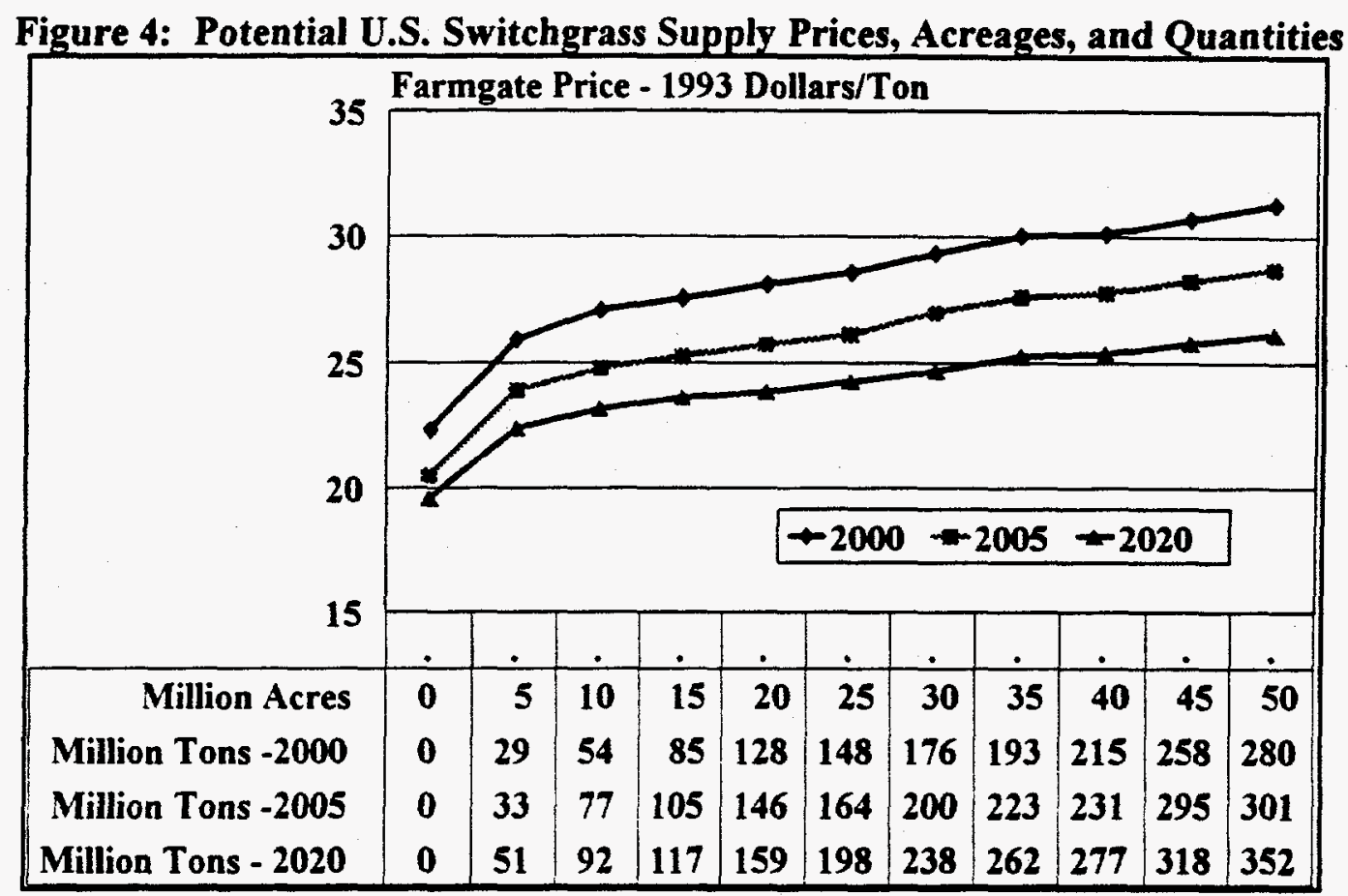

The quantities supplied in these estimates are very sensitive to price. This is consistent with the long run methodology used for the estimates and is appropriate for land currently idle. Experience with long-nin multi-crop estimates suggests that each quantity produced would require higher prices if biomass production significantly displaced existing crops.

Estimates for U.S. wood crop production on 50 million acres are shown in Figure 5 . The interpretation is the same as for Figure 4. The left part of the estimates at lower prices represent lower costs associated with willow production (relative to poplar). The supply estimates in these two figures include much of the same land. Therefore an additional calculation is needed in terms of a common energy metric, allowing either grass or wood production, to determine how much of each particular biomass crop is produced. Since wood and grass crops have different energy contents per ton, a combined estimate can be made by converting wood and grass tonnage to common energy units and prices. 
Figure 5: Potential U.S. Wood Crop Supply Prices, Acreages, and Quantities

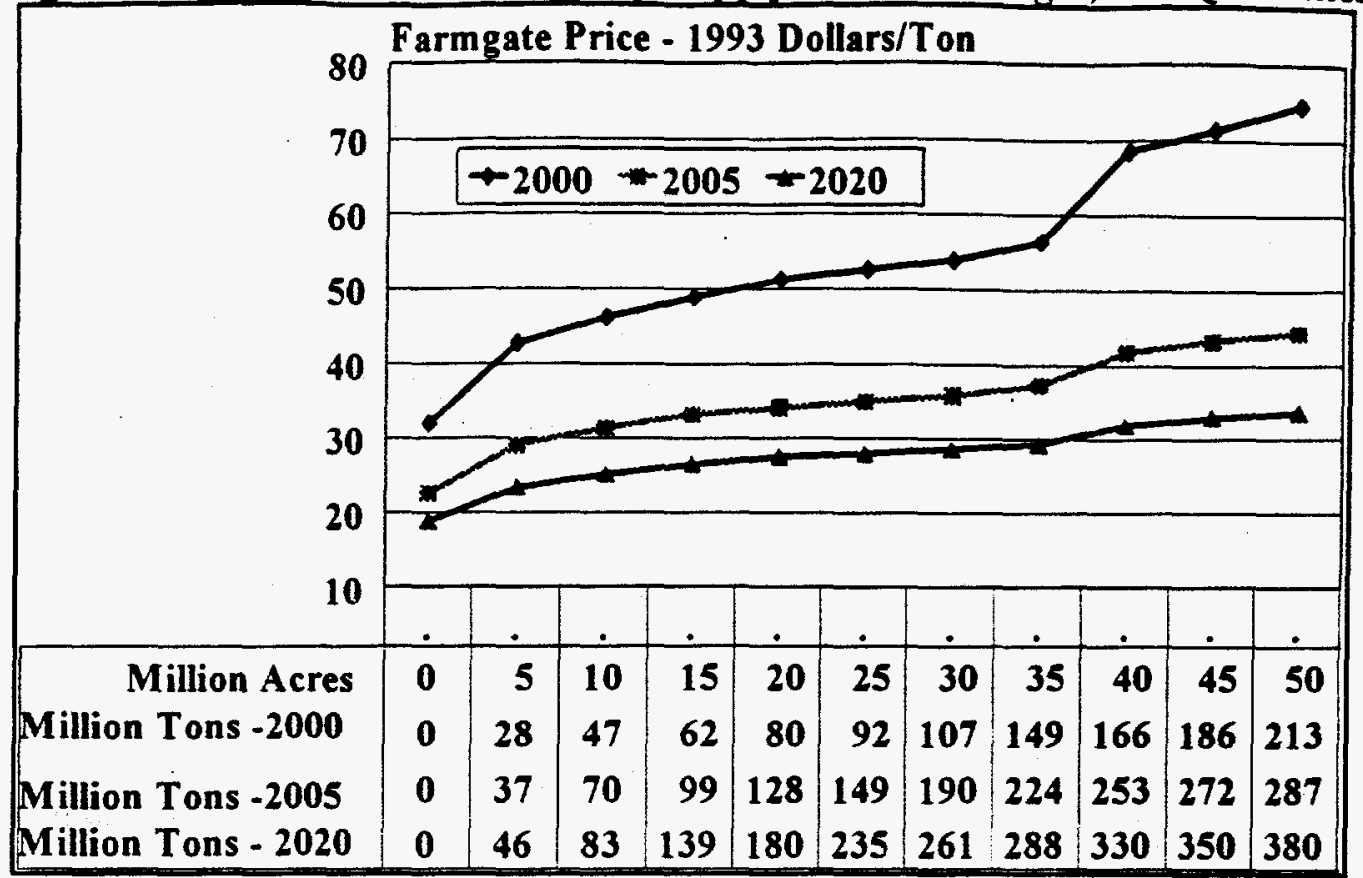

Assuming wood and grass crops contain 16.5 and 14.5 million Btu of energy per dry ton, respectively, the tonnage and prices shown above (with transport costs added) were converted to energy units. Ranking the data for about 50 million acres by energy prices and cumulating the energy content gives the national biomass supply in Figure 6.

Figure 6: Potential U.S. Biomass (Wood and Grass Crops) Energy Supply

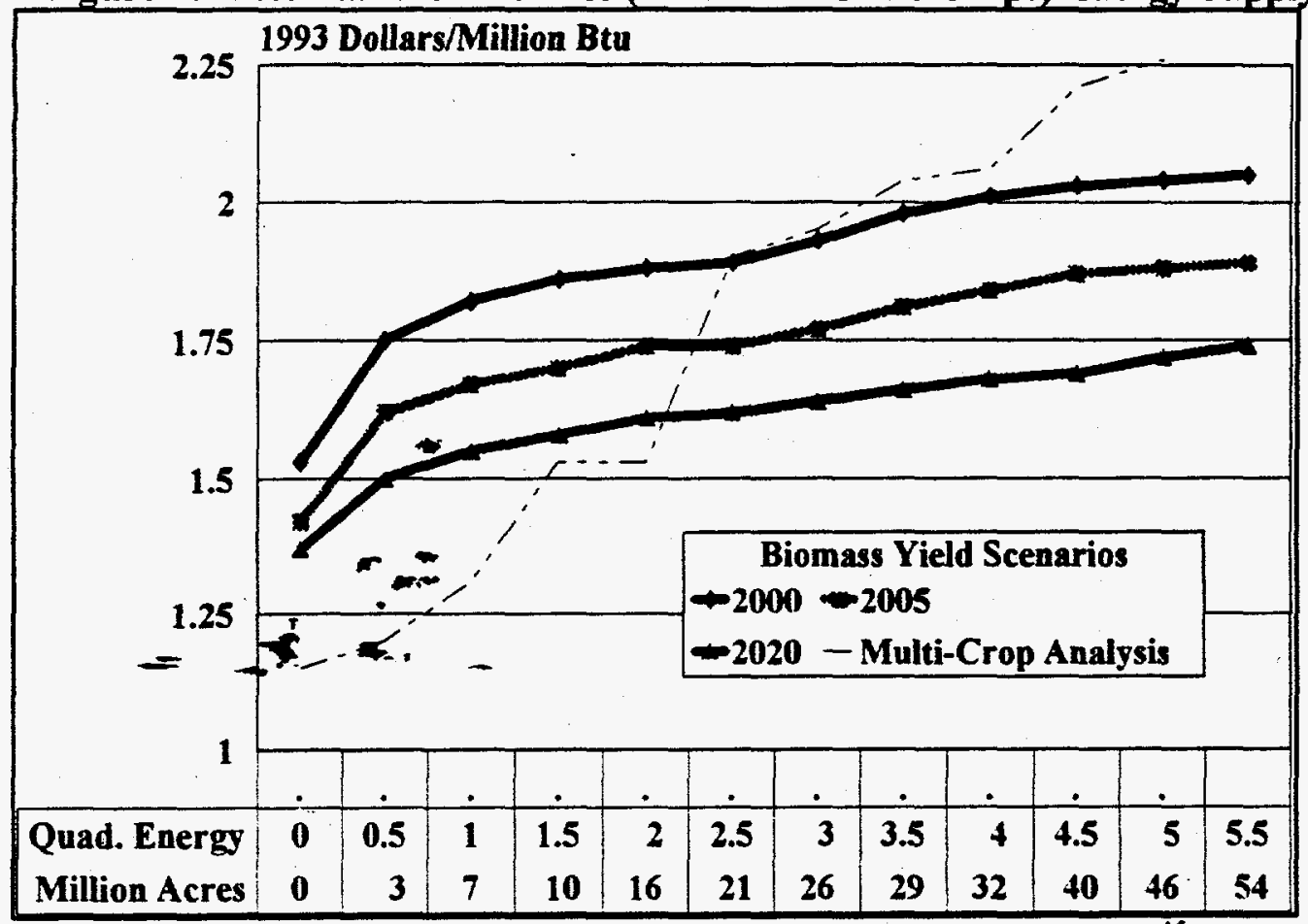

Note: Btu $\equiv$ British thermal unit of energy. One Quad. of energy $\equiv 10^{15} \mathrm{Btu}$.

As a point of reference, the U.S. consumed about 80 Quad. of energy in 1988. 
The steeper (dashed) line in Figure 6 shows an alternative biomass supply estimate by McCarl using a multi-crop model (Adams, et. al.) for 2020. At lower prices, the McCarl analysis includes waste wood. As the biomass acreage climbs above 30 million acres and biomass crops compete with existing ones, the multi-crop methodology suggests that higher prices would be needed to cause biomass to displace existing crop production.

Regardless of the estimated biomass supply in energy terms, additional assumptions about technology are required if biomass is to be evaluated exclusively for use as a fuel for electric power generation. Figure 7 summarizes some technical cost assumptions as three components of electricity prices. DOE and Electric Power Research Institute (EPRI) electric power cost assumptions for the three scenarios are shown at the right and are compared to other estimates using various energy sources, including biomass. Lower cost estimates in 2005 and 2020 basically assume greater cost and production efficiency using new generation gassification-gas turbine systems to convert biomass to electricity.

Figure 7: Estimates of Electricity Price Components

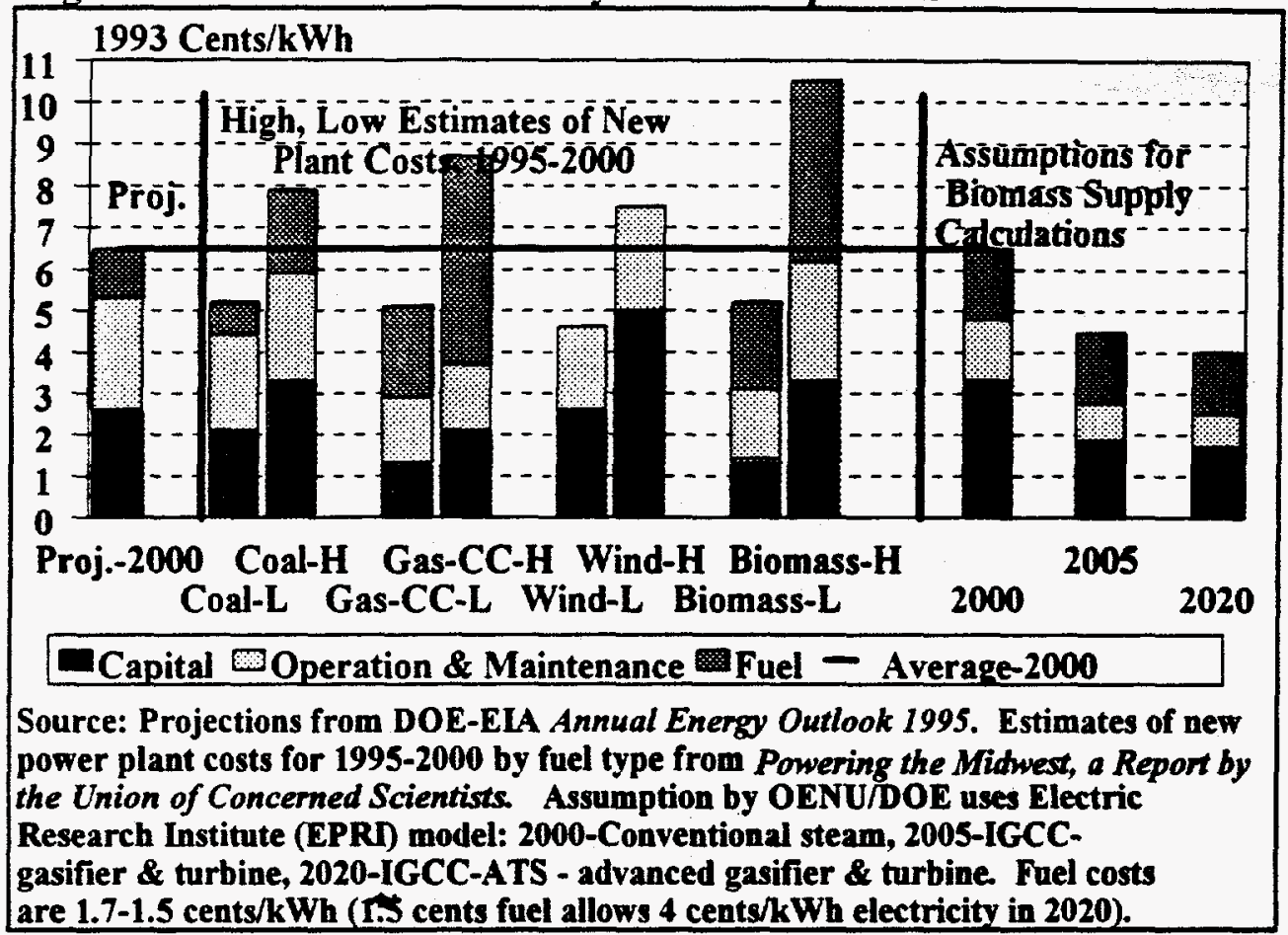

Since capital and operation and maintenance costs make up over half of the electricity price, their reduction with new technology is crucial to the attainment of a 4 cents per $\mathrm{kWh}$ biomass based lecticity price that is thought to be competitive with power production from other fuels in 2020 such as coal and natural gas. The power cost assumptions in Figure 7 are combined with the biomass energy supply estimates in Figure 6 to produce the potential biomass-based electricity supply for the three scenarios in Figure 8. An additional alternative scenario for 2020 assuming yields from 2000 gives electricity price estimates only 0.2 cents per $\mathrm{kWh}$ higher on average. Therefore the required cost reduction for competitive electricity production in 2020 in Figure 8 comes almost entirely from the new lower-cost electricity generation technology. If these cost assumptions hold true and if biomass production does not crowd out existing crops, then up to 50 million acres of competitive biomass crops might exist in the future. 
Figure 8: Potential Biomass Based Electricity Supply

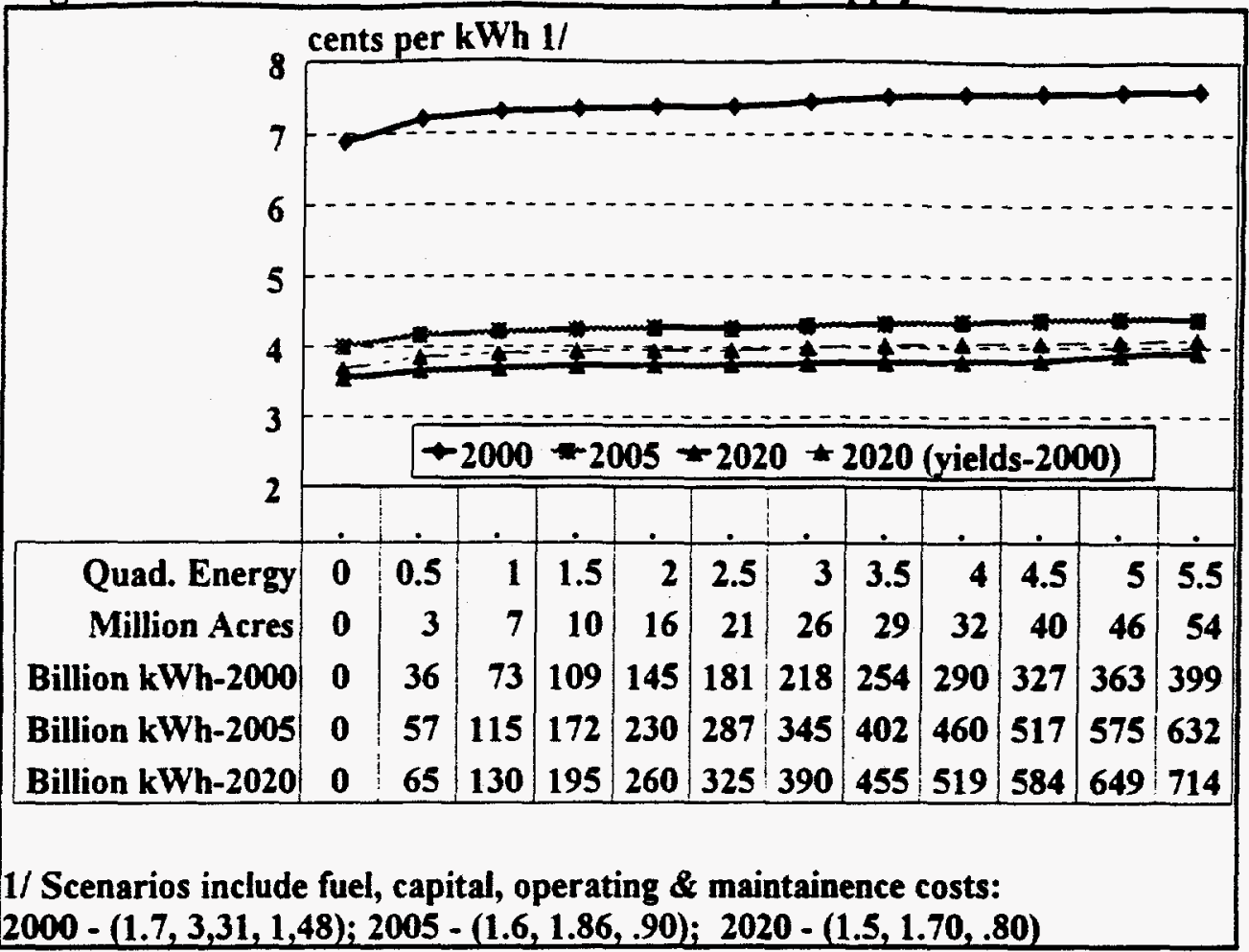

These calculations and underlying assumptions lead to a distribution of biomass supply by region and crop shown in Figure 9. Willows could become a major wood crop in the North East while switchgrass could be a major biomass crop in the other regions. Low cost power technology and improved feedstock production systems are keys to this future.

Figure 9: Estimated Regional Biomass Production by Crop for Power Generation Switchgrass (34 million acres) Wood Crops (20 million acres) 1/
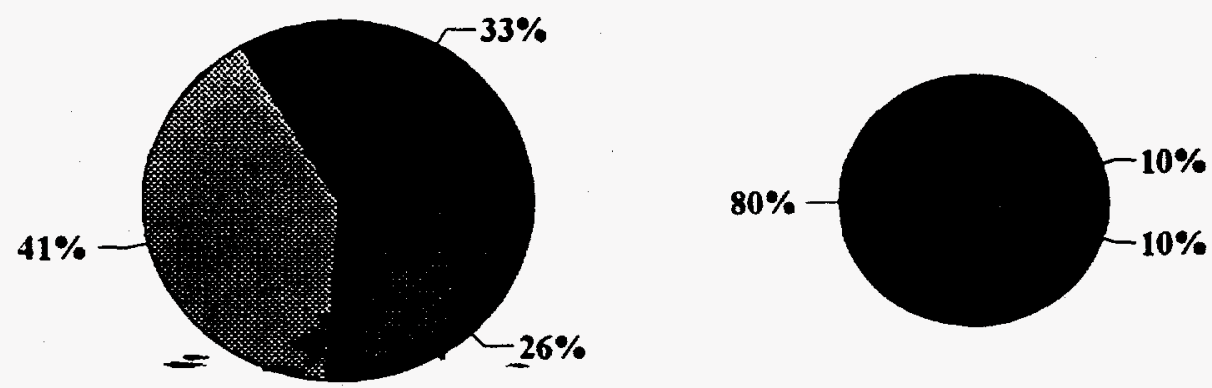

Regions of the United States
North Central WNorth East
South Central $\quad$ South East

1/ Poplar for the North Central, South Central, and South East Regions; Willows for the North East Region 
To summarize, biomass crops could become feedstocks for industrial uses, given optimistic assumptions about the success of research programs for production and utilization. The successful development of a new generation of efficient power generation technology could make biomass generated electricity a reality. Some low cost biomass production and biomass wastes such as wood, make a niche biomass power market possible now. Successful biomass research programs, rising fossil fuel prices, and/or biomass incentive policies could expand the biomass industry. However, the optimistic U.S. biomass scenarios assume that improved production, harvesting, delivery, and utilization systems implied by crop budgets and power/utilization cost estimates are in place. Much hard engineering, organizational, and research work will be required to demonstrate the workability of these systems. Future biomass farmers and processors need to see practical and successful demonstration projects on the ground that before they begin to participate on a large scale.

\section{References}

Adams, Darius, Ralph Alig, J.M. Callaway, and Bruce A. McCarl. 1994. Forest and Agricultural Sector Optimization Model: Model Description, a report prepared for the Environmental Protection Agency. Boulder, CO. RCG/Hagler Bailly.

Energy Information Administration (EIA), U.S. Department of Energy (DOE). 1995. Annual Energy Outlook 1995 With Projections to 2010. Washington, DC.

Energy Information Administration (EIA), U.S. Department of Energy (DOE). 1995. Supplement to the Annual Energy Outlook, 1995. Washington, DC.

Graham, Robin Lambert. 1994. "An Analysis of the Potential Land Base for Energy Crops in the Conterminous United States". In Biomass and Bioenergy, Vol. 6., No. 3. Oxford UK. Elsevier Science Ltd.

Osborn, C. Tim, Felix Liacuna, and Michael Linsenbigler. 1992. The Conservation Reserve Program (CRP), Enrollment Statistics for Sign-up Periods 1-11 and Fiscal Years 1990-1992. Economic Research Service (ERS) Statistical Bulletin Number 843. Washington, DC.

Strauss, Charles H., and Lyyfifl. Wright. 1990. "Woody Biomass Production Costs in the United States: In Solar Energy, Vol. 45. No. 2. Permagon Press Inc.

Union of Concerned Scientists. 1993. Powering the Midwest, Renewable Electricity for the Economy and the Environment, A Report by the Union of Concerned Scientists. Cambridge, MA. pp. 109-118.

Walsh, Marie E. and Robin L. Graham. 1995. "Biomass Feedstock Supply Analysis: Production Costs, Land Availability, Yields", a working report from the BioFuels Feedstock Development Program, Oak Ridge National Laboratory, Oak Ridge, TN. 